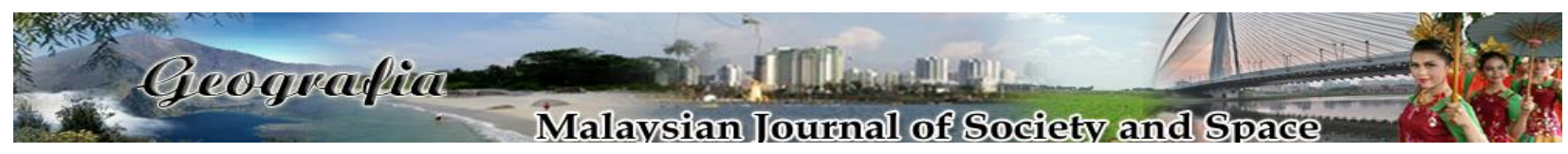

\title{
Persepsi pesakit-waris terhadap kejelasan maklumat dan hubungan perorangan dalam komunikasi di pusat perubatan
}

\author{
Zarina Othman ${ }^{1}$, Mohd Azman Abas ${ }^{2}$, Rozmel Abdul Latif ${ }^{1}$, Azizah Ya'acob ${ }^{1}$, Wan Nur'asyiqin Wan \\ Mohammad $^{1}$, Noorazmeira Nor'azman ${ }^{3}$ \\ ${ }^{1}$ Pusat Citra Universiti, Universiti Kebangsaan Malaysia \\ ${ }^{2}$ Pusat Kesihatan, Universiti Kebangsaan Malaysia \\ ${ }^{3}$ Pusat Penyelidikan Impak Sosial dan Industri Kreatif, Fakulti Sains Sosial dan Kemanusiaan, \\ Universiti Kebangsaan Malaysia
}

Correspondence: Zarina Othman (email: zarinao@gmail.com)

Received: 07 November 2018; Accepted: 17 January 2019; Publish: 22 February 2019

\begin{abstract}
Abstrak
Salah satu faktor yang menyumbang kepada persepsi umum masyarakat terhadap sesebuah organisasi adalah tahap kepuasan khidmat pelanggannya. Hal ini termasuklah khidmat pelanggan di pusat perubatan melibatkan komunikasi antara pihak pusat perubatan dan pesakit atau waris menjadi aduan atau rungutan masyarakat umum. Adakalanya, rungutan ini berfokus kepada unsur ketidakjelasan maklumat dan hubungan perorangan yang kurang profesional antara doktor dan pesakit atau waris dalam interaksi di klinik perubatan tertentu. Penulisan ini bertujuan mengkaji persepsi pesakit-waris terhadap aspek kejelasan maklumat dan hubungan antara perorangan di antara doktor-pesakit di salah sebuah pusat perubatan awam di Malaysia. Satu soal selidik temu bual yang mengadaptasi soal selidik PPE (15) (Picker Patient Experience) secara bersemuka terhadap 100 responden yang dipilih secara rawak. Hasil kajian menunjukkan peratusan tahap kepuasan pesakit-waris terhadap kejelasan maklumat serta hubungan antara perorangan agak memuaskan dengan catatan peratusan melebihi 50 peratus. Namun begitu, keprihatinan terhadap peratusan tahap ketidakpuasan pesakit-waris terhadap kejelasan maklumat dan hubungan antara perorangan antara doktor-pesakit masih perlu dipertingkatkan. Antara aspek kejelasan maklumat dalam dapatan kajian merangkumi maklumat penyakit serta pengambilan ubat-ubatan, manakala aspek hubungan perorangan merangkumi nilai dihormati, peluang pesakit-waris menyuarakan kebimbangan dan berinteraksi bersama doktor. Dapatan kajian ini memperlihatkan implikasi kajian terhadap keperluan bagi peningkatan tahap kesedaran dan profesionalisma yang tinggi dalam komunikasi doktor dan pesakit-waris.
\end{abstract}

Kata kunci: doktor, pesakit-waris, hubungan perorangan, interaksi, kejelasan maklumat, komunikasi 


\title{
Patients-next of kins' perceptions on information clarity and interpersonal relations in communication in a medical practice
}

\begin{abstract}
One of the factors that contributes to the general perception of society towards an organisation is the level of customer service satisfaction. This includes customer service at medical centers, where communication between staff and patient or their next of kin becomes a common complaint from the public. Occasionally, these complaints focus on clarity of information and lack of interpesonal skills between doctors and patients-next of kin in the doctor-patient interaction in the clinics. This study aims to examine the perceptions of patients in terms of the clarity of information and the interpersonal skills between doctor-patient in one of the public medical centers in Malaysia. A face-to-face survey questionaire interview adapted from PPE (15) (Picker Patient Experience) with 100 randomly selected respondents was conducted at a public medical center. The findings illustrate that more than 50 percent of respondents are satisfied with regards to clarity of information and interpersonal relations between doctor-patient. However, there still exist percentages of dissatisfaction among patient-next of kin that should be given considerable attention. The clarity of information is needed in conveying clarity of illnesses and medicine takings whilst the interpersonal skills composite the need to feel respected as patientnext of kin and opportunities to express concerns and to interact with doctors. The findings of this study demonstrate the the need to enhance level of profesionalism focusing on customer service communication between doctors and patients.
\end{abstract}

Keywords: doctor, patient-next of kin, interpersonal relationship, interaction, information clarity, communication

\section{Pengenalan}

Komunikasi profesional dalam konteks amalan perkhidmatan pelanggan di pusat perubatan adalah satu unsur penting yang akan mempengaruhi persepsi dan kepuasan pesakit atau waris pesakit. Merujuk kepada kod etika profesional, penggunaan ilmu pengetahuan yang dimiliki oleh pengamal perubatan perlu dilaksanakan secara efektif bagi mempertingkatkan kesejahteraan sosial (Florian, 2008). Amalan etika berkomunikasi dalam industri perubatan juga penting dan suatu keperluan untuk ahli profesion perubatan lain seperti jururawat, ahli farmasi dan lain-lain. Normah et al. (2014) menekankan bahawa kualiti perkhidmatan perubatan memainkan peranan utama terhadap tahap kepuasan dan persepsi para pelanggan. Secara amnya, persepsi pesakit terhadap ketidakpuasan perkhidmatan perubatan semakin meningkat dan fenomena ini menyebabkan hubungan di antara doktor-pesakit akan terjejas (Pronovost et al., 2003).

Peranan doktor dalam komunikasi membantu menjalinkan hubungan antara perorangan yang baik dan memberi kesan signifikan terhadap penjagaan kesihatan pesakit (Shukla et al., 2010). Unsur komunikasi yang diaplikasikan secara lisan atau tanpa lisan turut mempengaruhi persepsi pesakit dari aspek kepuasan, perkongsian maklumat dan hubungan antara perorangan. Pesakitwaris mengalami keterbatasan dalam berinteraksi dengan doktor, mahupun kakitangan pusat perubatan (Gunasegaran, 2014). Sikap doktor terhadap pesakit, keupayaan doktor dalam 
mendapatkan maklumat yang jelas, memahami situasi serta berupaya mengatasi tahap kebimbangan pesakit adalah komponen utama dalam usaha membantu mempertingkatkan tahap kepuasan pesakit. Oleh itu, komunikasi yang berkesan berupaya mempertingkatkan tahap kepuasan pesakit terhadap rawatan yang diberikan oleh doktor (Woodhead et al., 2015). Kajian ini bertujuan untuk mengkaji persepsi pesakit atau waris pesakit dalam konteks amalan profesional komunikasi di pusat perubatan. Kajian ini meneroka persepsi pesakit-waris terhadap hubungan di antara kejelasan maklumat antara doktor-pesakit dan hubungan antara perorangan dalam interaksi berkomunikasi doktor-pesakit atau waris pesakit.

\section{Kajian literatur}

\section{Kejelasan maklumat dalam komunikasi mempengaruhi persepsi pesakit-waris}

Doktor perubatan merupakan individu yang bertanggungjawab memberi rawatan kesihatan kepada pesakit dan komunikasi adalah medium perantaraan yang dipraktikkan sepanjang perkhidmatan berlangsung. Interaksi doktor dan pesakit atau waris adalah ruang dan peluang kepada doktor menyalurkan maklumat kesihatan kepada pesakit-waris dari masa ke semasa. Kejelasan maklumat memerlukan teknik penyebaran informasi melalui amalan komunikasi yang berkesan. Shukla et al. (2010) menekankan bahawa keupayaan doktor dalam mendapatkan dan menyalurkan maklumat yang jelas berupaya mengatasi kebimbangan dan kekhuatiran pesakit mengenai masalah kesihatan yang dihadapi. Gaya komunikasi semasa memberi penerangan maklumat memerlukan strategi yang sistematik menerusi penggunaan bahasa yang mudah difahami. Kewujudan jalinan komunikasi yang baik dan lancar serta kombinasi di antara penerangan dan pemahaman doktor-pesakit akan menjadi seiring yang memberi hasil positif kepada perkongsian ilmu, motivasi, keseimbangan emosi, pembentukan budaya, dan kesihatan.

Saiboon et al. (2008) menyatakan bahawa tanggapan atau penerimaan pesakit terhadap penjelasan doktor bergantung kepada informasi yang diperolehi. Kejelasan maklumat yang diberikan menyumbang kepada persepsi dan kepuasan pesakit. Landasan ini menjadi pengukuran penting dalam mempertingkatkan kefahaman pesakit untuk menghasilkan kesihatan yang cemerlang. Penjagaan kesihatan boleh terjejas sekiranya pesakit-waris mengalami keterbatasan maklumat mengenai masalah kesihatan yang dialami. Doktor mahupun kakitangan pusat perubatan perlu bertindak aktif dengan mempromosikan literasi kesihatan dan memperbaiki teknik penyaluran maklumat secara sistematik (Ahrens \& Wirges, 2013). Linebarger (2014), menegaskan penjagaan pesakit secara menyeluruh merupakan suatu pendekatan yang berasaskan falsafah dengan memberi perkhidmatan terhadap keperluan pesakit dari segi fizikal, psikologi dan sosial. Pusat perubatan perlu melaksanakan perubatan secara holistik bagi memastikan kualiti perkhidmatan kesihatan terjamin dan mendapat penilaian yang positif daripada pesakit.

Seterusnya, Miric et al. (2008) berpendapat bahawa kecekapan dan kemahiran komunikasi adalah suatu keutamaan dalam usaha membina hubungan baik di antara doktor-pesakit. Doktor dan kakitangan perlu memberikan pendidikan kepada pesakit bagi memastikan pesakit memahami secara terperinci tentang masalah kesihatan dan perancangan rawatan yang sedang dijalankan. Inisiatif ini secara langsung mempengaruhi persepsi pesakit untuk berusaha memulihkan masalah kesihatan yang dihadapi. Peranan pesakit dalam penjagaan kesihatan bergantung kepada perolehan dan pemahaman maklumat yang disalurkan oleh doktor. Pemaparan sifat berdedikasi, positif, menghormati, empati, memahami situasi pesakit, adalah 
antara insiatif yang membantu mempertingkatkan persepsi dan kepuasan pesakit (Williams et al., 2002). Kejelasan maklumat juga berperanan memimpin pesakit melibatkan diri dalam proses penjagaan kesihatan yang tersusun. Melalui pemahaman yang jelas dan motivasi yang tinggi, pesakit akan lebih bersedia mematuhi arahan rawatan, berupaya mengambil bahagian dalam penjagaan diri mereka dan tidak menyalah tafsir tujuan dan kesan rawatan. Kejelasan maklumat juga perlu disalurkan kepada ahli keluarga atau penjaga pesakit mengikut kesesuaian dan keperluan kerana mereka juga antara individu yang turut membantu merawat kesihatan pesakit.

Keterampilan personaliti doktor dalam berkomunikasi dengan pesakit seperti memaparkan nilai simpati turut menjadi kepentingan, terutamanya semasa proses perbincangan. Hal ini kerana ianya bermain dengan perasaan pesakit-waris yang mungkin berada dalam keadaan yang tidak stabil. Pendekatan ini memberi impak positif kepada keadaan kesihatan pesakit. Berdasarkan Lerman et al. (1993), mekanisma pesakit untuk berhadapan dengan tekanan akan berkurangan sekiranya doktor dan kakitangan pusat perubatan dapat menjalankan etika komunikasi secara berkesan. Etika komunikasi yang berjaya dipraktikkan oleh doktor membantu pesakit mengurangkan masalah psikologi seperti kemurungan yang berpanjangan. Kejelasan maklumat daripada doktor atau kakitangan pusat perubatan juga membantu mempertingkatkan keyakinan pesakit. Di samping itu, bersikap toleransi dengan pesakit dan sentiasa membuat perbincangan mengenai kaedah rawatan antara tindakan yang wajar dilakukan oleh doktor dan kakitangan pusat perubatan.

\section{Hubungan antara perorangan dalam komunikasi}

Hubungan antara perorangan (interpersonal relationship) mempunyai hubung kait dalam mempengaruhi persepsi pesakit-waris. Layanan doktor dan kakitangan pusat perubatan dalam hubungan antara perorangan boleh memberi impak besar kepada perkembangan kesihatan pesakit (McKinley et al., 2001). Komunikasi antara perorangan merupakan proses interaksi yang berlaku antara individu dengan individu lain menggunakan komunikasi verbal dan bukan verbal (Hartley, 1993). Penyampaian dan perkongsian informasi yang disampaikan jelas dan mudah untuk difahami oleh pesakit atau waris dapat menjalinkan relasi yang baik. Setiap anggota organisasi perlu mengamalkan komunikasi secara harmoni (Beaulieu et al., 2011).

Hubungan antara perorangan dapat membentuk jalinan hubungan komunikasi yang terapeutik. Hubungan terapeutik ialah hubungan doktor-pesakit untuk tujuan membantu dan menggalakkan kesihatan serta pemulihan pesakit dari semasa ke semasa. Komunikasi secara verbal adalah penggunaan bahasa yang mengandungi nilai moral yang tinggi seperti menghargai, memberi harapan, prihatin, kasih sayang, perhatian dan sebagainya. Manakala, komunikasi secara bukan verbal akan terjalin melalui pendengaran yang baik, sentuhan, senyuman, hubungan mata dan sebagainya (Dickert, 2009). Pendekatan ini bertujuan membina dan membantu meredakan emosi pesakit yang berhadapan dengan masalah kesihatan. Pengkaji seperti Benson (2014), Shukla et al. (2010) dan Woodhead et al. (2015) merumuskan bahawa unsur komunikasi dalam amalan khidmat perubatan merupakan suatu pendekatan penting dalam menjalinkan hubungan komunikasi yang beretika. 


\section{Metod dan kawasan kajian}

Kaedah kajian ini secara utamanya berbentuk kuantitatif iaitu pengumpulan data melalui soal selidik yang diadaptasi daripada PPE (15) (Picker Patient Experience) yang diperolehi daripada Jenkinson et al. (2002). PPE (15) adalah satu instrumen kaji selidik yang dibina untuk mengukur pengalaman pesakit yang menjalani rawatan kesihatan di pusat rawatan kesihatan. Soalan dalam instrumen ini dipilih daripada bank soalan yang dibina hasil daripada kaji selidik pesakit dalaman yang dijalankan oleh Institut Picker bagi tujuan mengukur kualiti tahap keperhatian yang diberi dalam rawatan kesihatan. Kaji selidik ini mengandungi 15 soalan item terpilih dan item ini telah diperaku mempunyai kesahihan yang tinggi. Soalan kaji selidik ini juga mempunyai tahap kesahan konstruk dan konsisten kebolehpercayaan dalaman yang tinggi.

Satu pendekatan kaedah soal selidik bersemuka bagi membuka rasa sukarela responden untuk menjawab soal selidik ini telah diberi perhatian dan dikemukakan secara lisan kepada responden. Soal selidik ini disediakan dalam dwibahasa iaitu Bahasa Melayu dan Bahasa Inggeris bagi mengatasi kesukaran responden yang tidak fasih berbahasa Melayu. Kajian dilaksanakan di salah sebuah pusat perubatan awam di ibu kota Kuala Lumpur, Malaysia. Lokasi untuk mengenal pasti responden dilakukan di klinik perubatan dan unit pengambilan ubat memandangkan kajian secara rintis yang dijalankan sebelum ini mendapati pesakit-waris lebih sukarela bersetuju diberikan temu bual soal selidik ini.

Pemilihan responden adalah secara rawak melibatkan seramai 100 responden berumur antara umur 20 hingga 50 tahun yang merupakan pesakit-waris di sebuah pusat perubatan awam. Dapatan hasil kajian kuantitatif ini dianalisis menggunakan perisian Statistical Package for Social Science (SPSS) 20. Dapatan analisis berbentuk deskriptif memaparkan persepsi pesakit waris terhadap hubungan di antara doktor-pesakit daripada aspek kejelasan maklumat dan hubungan antara perorangan melalui persepsi pesakit.

\section{Hasil kajian dan perbincangan}

\section{Profil demografi}

Profil demografi seperti jantina, bangsa, umur, kaum, kategori responden, tempoh penggunaan perkhidmatan dan jenis penyakit dijelaskan dalam Jadual 1. Seramai 100 responden adalah pesakit-waris yang terlibat dalam memberi maklum balas borang soal selidik temu bual ini. Pemilihan responden menepati sasaran kajian iaitu mengfokuskan kepada pesakit-waris yang mempunyai pengalaman dalam berkomunikasi dengan doktor dan kakitangan di pusat perubatan. Jadual 1 memaparkan taburan responden mengikut jantina, umur, kaum, kategori responden dan tempoh penggunaan perkhidmatan.

Jadual 1. Profil responden

\begin{tabular}{lccc}
\hline Pemboleh ubah & Kategori & Bilangan & Peratus (\%) \\
\hline Jantina & Lelaki & 46 & 46.0 \\
& Perempuan & 54 & 54.0 \\
Umur & $20-29$ tahun & 12 & 12.0 \\
& 30-39 tahun & 21 & 21.0 \\
& $40-49$ tahun & 11 & 11.0
\end{tabular}




\begin{tabular}{lccc} 
& 50 tahun ke atas & 56 & 56.0 \\
Kaum & Melayu & 80 & 80.0 \\
& Cina & 13 & 13.0 \\
& India & 6 & 6.0 \\
& Lain-lain & 1 & 1.0 \\
& Pesakit & 62 & 62.0 \\
Tempoh penggunaan & Waris & 38 & 38.0 \\
perkhidmatan di pusat & Kurang dari 1 tahun & 25 & 25.0 \\
perubatan & $1-5$ tahun & 29 & 29.0 \\
& 6-10 tahun & 19 & 19.0 \\
Jenis Penyakit & 10 tahun dan ke atas & 27 & 27.0 \\
& Penyakit kronik & 79 & 79.0 \\
\hline
\end{tabular}

Hasil kajian demografi menunjukkan 54.0\%pesakit-waris adalah perempuan dan $46.0 \%$ adalah lelaki. Merujuk kepada kategori umur, majoriti pesakit-waris berumur di antara 50 tahun dan ke atas seramai 56 orang dengan catatan $56.0 \%$, mencatat kedudukan paling tinggi. Diikuti dengan $21.0 \%$ bagi pesakit-waris lingkungan umur 30 hingga 39 tahun. Seterusnya, $12.0 \%$ mewakili pesakit-waris yang berumur 20 hingga 29 tahun. Bagi yang berumur 40 hingga 49 tahun pula mencatatkan peratusan paling rendah iaitu $11.0 \%$.

Berdasarkan Jadual 1, hasil dapatan kajian demografi juga menunjukkan bahawa $25.0 \%$ responden telah menjalani tempoh penggunaan perkhidmatan di pusat perubatan ini selama kurang daripada 1 tahun. Manakala didapati $29.0 \%$ responden telah menjalani tempoh rawatan di antara 1-5 tahun, $19.0 \%$ telah menjalani tempoh perkhirmatan selama 6-10 tahun dan 27 peratus responden telah menajalani tempoh rawatan selama lebih daripada 10 tahun. Dapatan analisis kajian demografi ini juga mendapati, $79.0 \%$ responden mengalami jenis penyakit yang kronik, manakala $21.0 \%$ adalah pesakit yang menjalani rawatan bagi penyakit acute.

\section{Aspek kejelasan maklumat}

\section{a. Kejelasan maklumat mempengaruhi persepsi pesakit}

Berdasarkan Rajah 1, 70.0\% menyatakan 'Ya, selalunya' apabila pesakit-waris mempunyai soalan penting untuk diajukan kepada doktor, respons yang diterima oleh pesakit senang untuk difahami. Pesepsi pesakit-waris terhadap kejelasan maklumat dalam komunikasi semasa menjalankan rawatan harian menunjukkan keputusan positif bagi pengaruh komunikasi dalam rawatan kesihatan. Sejumlah $28.0 \%$ pesakit-waris berpendapat 'Ya, kadang-kadang' mereka mendapat jawapan yang senang difahami. Sesetengah pesakit-waris berpendapat sesetengah doktor menggunakan bahasa Inggeris apabila menerangkan maklumat. Hal ini menyukarkan pesakit-waris yang mengalami masalah untuk menguasai bahasa tersebut. Keterbatasan maklumat yang dihadapi pesakit-waris menurunkan tahap kepuasan dan persepsi pesakit terhadap kemampuan perkhidmatan perubatan. Hasil kajian menunjukkan sejumlah $1.0 \%$ pesakit beranggapan tidak mendapat penjelasan yang jelas dari aspek informasi daripada doktor adalah pesakit-waris yang pernah berhadapan salah faham maklumat dan sikap doktor yang kurang memberi kerjasama terhadap kebimbangan dan kekhuatiran pesakit. 


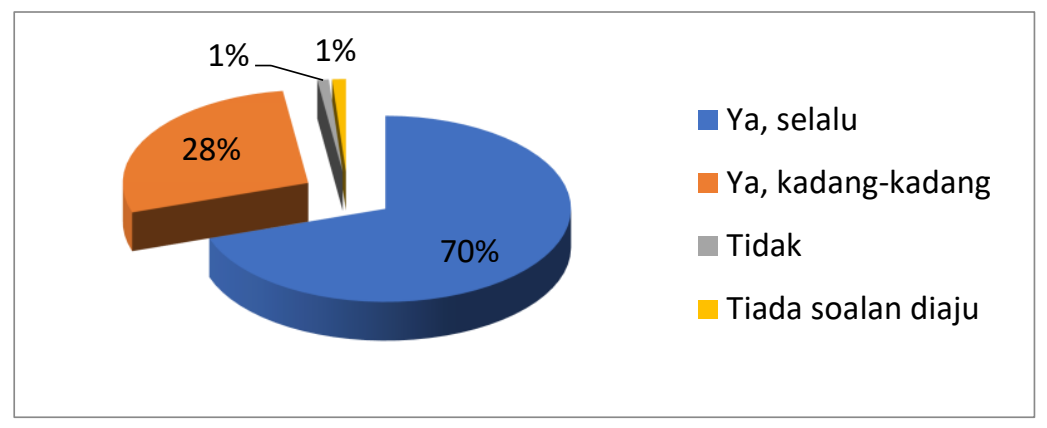

Rajah 1. Kejelasan maklumat

b. Ketepatan kejelasan maklumat kepada pesakit-waris

Merujuk Rajah 2, 51.0\% pesakit-waris berpendapat, mereka 'Tidak' mengalami kecelaruan informasi daripada doktor dan jururawat. Walau bagaimanapun, $42.0 \%$ pesakit-waris berpendapat 'Ya, kadang-kadang', mereka menerima kecelaruan informasi daripada doktor dan jururawat dan $7.0 \%$ mengatakan 'Ya selalunya'. Sebagai contoh, apabila pesakit-waris mengajukan soalan, tindak balas kakitangan pusat perubatan menunjukkan bahawa ketelitian kakitangan dalam mendapatkan maklumat pesakit adalah menurun. Jelas menunjukkan bahawa doktor dan kakitangan pusat perubatan perlu mempertingkatkan kesedaran terhadap isu kualiti ketepatan kejelasan maklumat bagi mengelakkan daripada berlaku kecelaruan maklumat dalam kalangan pesakit-waris.

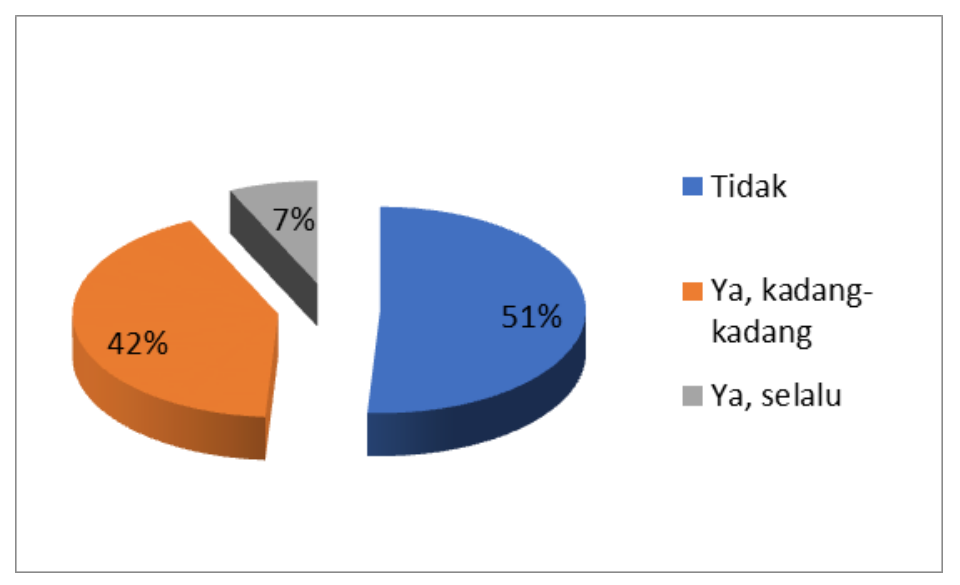

Rajah 2. Ketepatan kejelasan maklumat

c. Pendedahan maklumat yang jelas kepada pesakit-waris

Analisis seterusnya menunjukkan bahawa doktor-jururawat memberi maklumat dan penjelasan yang tepat seperti yang dikehendaki oleh pesakit-waris bagi membantu pesakit kembali sembuh. Persepsi bahawa 'Ya, sedikit sebanyak', mencatat nilai peratusan paling tinggi iaitu 48.0\%. Penjelasan maklumat bertujuan untuk memudahkan dan membolehkan pesakit-waris mencapai potensi mereka terhadap kesihatan dengan menghargai kesihatan sebagai aset yang berharga dan mengambil insiatif serta tanggungjawab yang positif (Ranjan et al., 2015). Seterusnya, persepsi 
'Ya, sepenuhnya' mencatat nilai peratus sebanyak 46.0\%. Manakala, persepsi 'Tidak' mendapat pendedahan maklumat mencatat nilai 4.0\%. Di samping itu, 'Tidak, tidak ada waris atau seseorang yang rapat terlibat', juga mencatat $2.0 \%$.

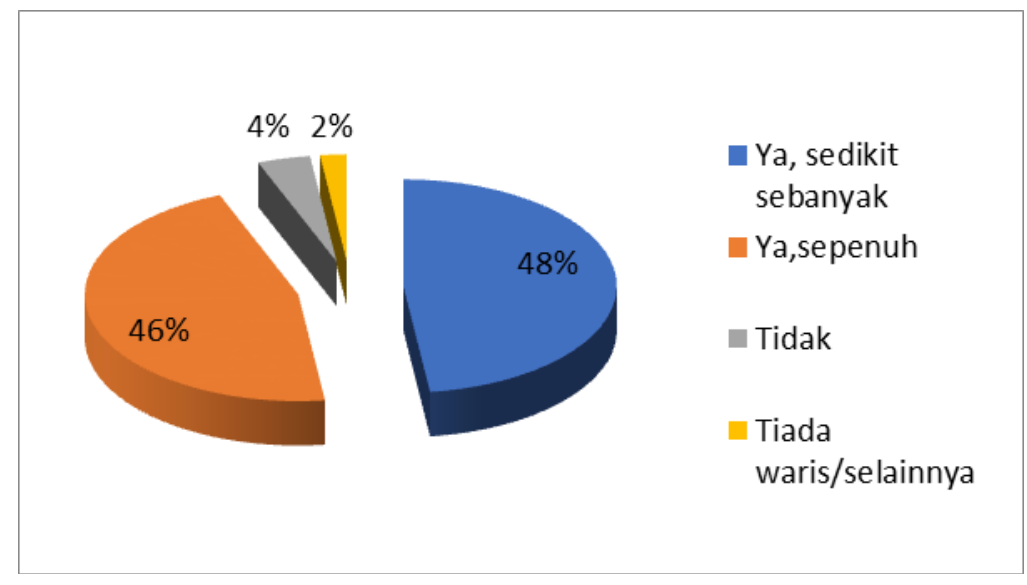

Rajah 3. Kejelasan pendedahan maklumat

Kesimpulannya, kakitangan pusat perubatan perlu peka dan konsisten dalam memberi tindak balas yang positif kepada pesakit-waris apabila ditanya. Ini kerana, penerangan yang mengandungi fakta yang jelas dirasakan lebih membantu untuk melahirkan persepsi yang positif dalam kalangan pesakit-waris.

d. Kejelasan maklumat terhadap tujuan pengambilan ubat-ubatan

Kebanyakan pesakit tidak memahami sepenuhnya tentang tujuan pengambilan ubat-ubatan. Sesetengah pesakit beranggapan pengambilan ubat sekadar untuk menahan dan bukan untuk membantu merawat penyakit. Merujuk Rajah 4, respons tentang 'Ya, sepenuhnya' pesakit-waris mendapat kejelasan maklumat terhadap tujuan pengambilan ubat mencatat $74.0 \%$. Manakala, $21.0 \%$ berpendapat 'Ya, sedikit sebanyak' atas sebab maklumat berkaitan tempoh pengambilan ubat kurang diberi penerangan kepada pesakit. Hasil dapatan menunjukkan $5.0 \%$ responden mengatakan mereka 'Tidak' mendapat kejelasan maklumat. Penerangan yang kurang jelas mengenai ubat-ubatan akan mengganggu perancangan rutin pengambilan ubat-ubatan seharian pesakit. Keadaan ini sering dihadapi oleh penyakit kronik seperti tekanan darah tinggi dan diabetes kerana perlu mengambil ubat dalam jangka masa yang panjang. 


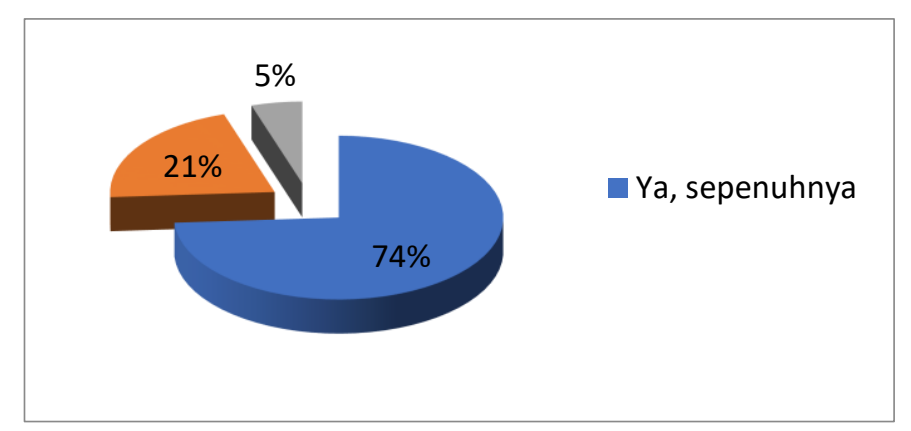

Rajah 4. Kejelasan maklumat terhadap tujuan pengambilan ubat

e. Kejelasan maklumat terhadap kesan sampingan pengambilan ubat-ubatan

Kejelasan maklumat terhadap kesan sampingan pengambilan ubat-ubatan kepada pesakit adalah suatu keperluan yang perlu dipenuhi dalam piawaian unit perubatan. Mengikut Kirkcaldy et al. (2018), keberkesanan ubat-ubatan juga turut mengandungi risiko yang tersendiri. Berdasarkan Rajah 5, 53.0\% responden bersetuju bahawa 'Ya, sepenuhnya' kejelasan maklumat tentang kesan sampingan pengambilan ubat diberikan. Manakala, seramai 31.0\% responden berpendapat bahawa 'Ya, sedikit sebanyak' kejelasan maklumat tentang kesan sampingan ini diberikan mencatat nilai kedua paling tinggi. Seterusnya, adalah perlu diberi perhatian kepada $15.0 \%$ respons yang mengatakan mereka 'Tidak' mendapat kejelasan maklumat terhadap kesan sampingan pengambilan ubat. Pesakit-waris tidak didedahkan dengan kejelasan maklumat berkenaan ubat-ubatan. Akhir sekali, pesakit-waris berpendapat 'Tidak, saya tidak perlukan sebarang penjelasan' mencatat peratusan hanya $1.0 \%$.

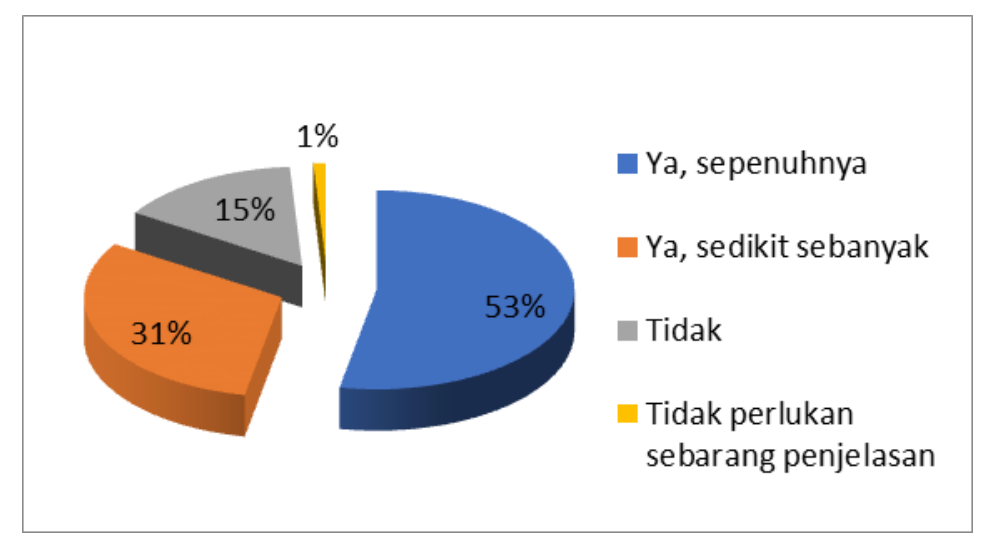

Rajah 5. Kejelasan maklumat terhadap kesan sampingan pengambilan ubat

f. Kejelasan maklumat terhadap tanda bahaya yang perlu diawasi semasa di rumah

Berdasarkan Rajah 6, 56.0\% berpendapat 'Ya, sepenuhnya' pesakit-waris diberi penerangan yang jelas mengenai tanda-tanda bahaya ubat dan rawatan yang perlu dikenal pasti serta awasi semasa di rumah dan 36.0\% mengatakan 'Ya, sedikit sebanyak'. Kirkcaldy et al. (2018) 
menyatakan bahawa kakitangan pusat perubatan, khususnya perlu memberi panduan dan rujukan kepada pesakit-waris tentang langkah keselamatan ubat-ubatan yang perlu diawasi di rumah

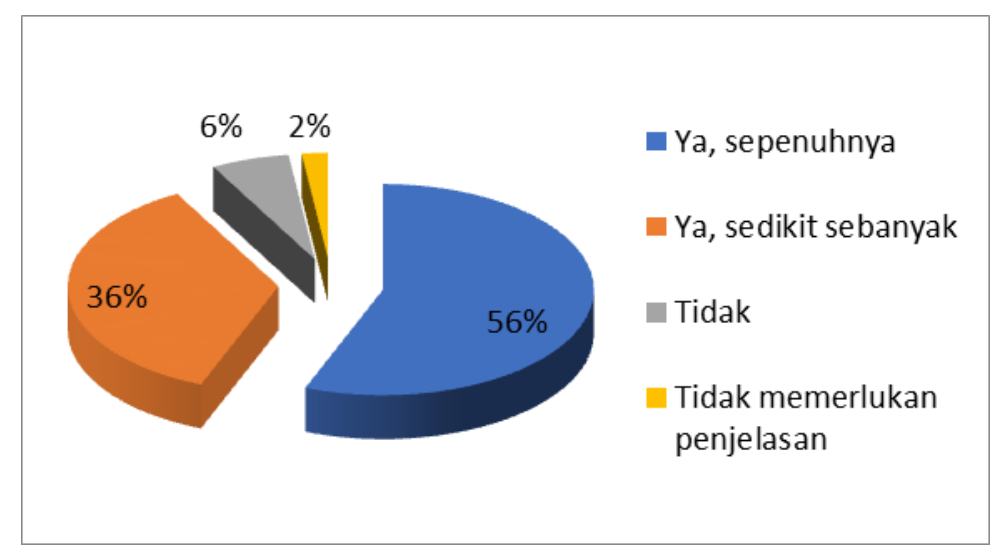

Rajah 6. Kejelasan Maklumat Terhadap Tanda Bahaya Ubat

Sejumlah $6.0 \%$ responden menjawab mereka 'Tidak' mendapat kejelasan maklumat terhadap tanda bahaya ubat mencatat nilai sebanyak. Manakala, 2.0\% merasakan 'Tidak, saya tidak perlukan sebarang penjelasan'. Kejelasan maklumat yang diberikan turut membantu meningkatkan disiplin pesakit dalam usaha merawat kesihatan (Williams et al., 2014). Sehubungan itu, dapat disimpulkan bahawa etika komunikasi dalam kehidupan membantu menggerakkan dan melancarkan unit sosial ke arah positif.

\section{Aspek hubungan antara perorangan (Interpersonal Relationship)}

a. Menghargai pesakit dengan nilai menghormati

Merujuk Rajah 7, pernyataan bahawa doktor bercakap di hadapan pesakit, tetapi seolah-olah seperti pesakit tiada di situ telah mendapat respons sebanyak 73.0\% iaitu 'Tidak' berlaku ke atas mereka. Ini menunjukkan kadar nilai menghormati yang diamalkan dalam kalangan pengamal profesional adalah tinggi.

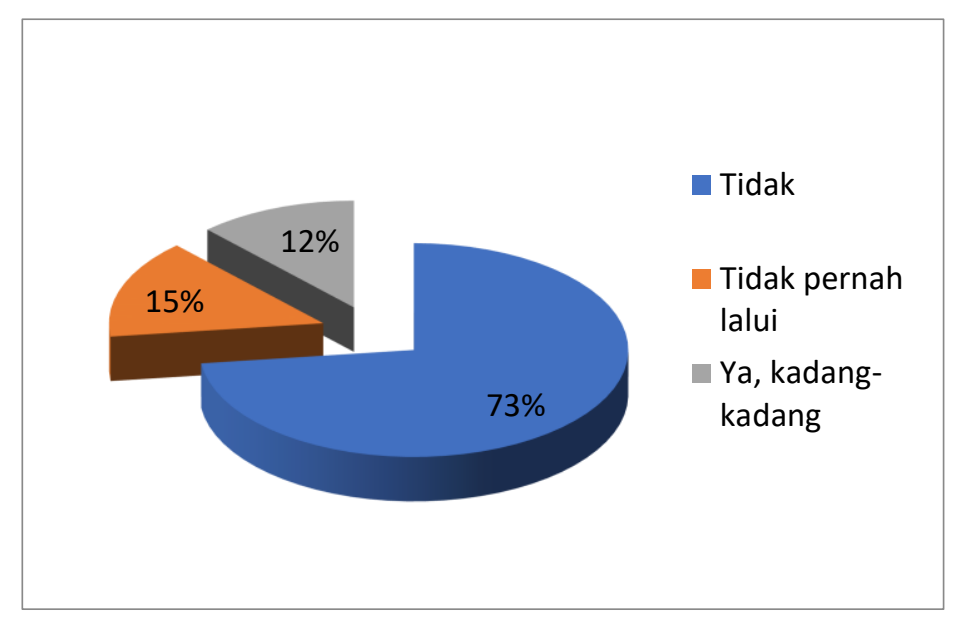

Rajah 7. Tidak menghargai pesakit dengan nilai menghormati 
Seterusnya, $15.0 \%$ menyatakan mereka 'Tidak pernah lalui' situasi ini. Walau bagaimanapun, terdapat $12.0 \%$ pesakit-waris yang menyatakan pernah 'kadang-kadang' mengalami situasi iaitu doktor menunjukkan reaksi seperti bercakap di hadapan pesakit seolaholah pesakit tiada di situ. Ekspresi wajah, intonasi suara dan budi bahasa boleh menimbulkan kesan dan persepsi yang menentukan penerimaan individu secara positif, mahupun negatif. Miric et al. (2008) menekankan bahawa wajah merupakan alat komunikasi yang sangat penting dalam menyampaikan maklumat.

\section{b. Menyuarakan kebimbangan dan kekhuatiran kesihatan kepada doktor}

Sifat keterbukaan doktor dan kakitangan serta menampilkan kejujuran dalam setiap tugasan yang terlaksana, berupaya menarik kepercayaan pesakit-waris untuk meluahkan rasa kebimbangan mereka mengenai keadaan kesihatan. Merujuk Rajah 8, seramai $77.0 \%$ pesakit-waris menyatakan kebimbangan mereka mengenai kesihatan kepada doktor.

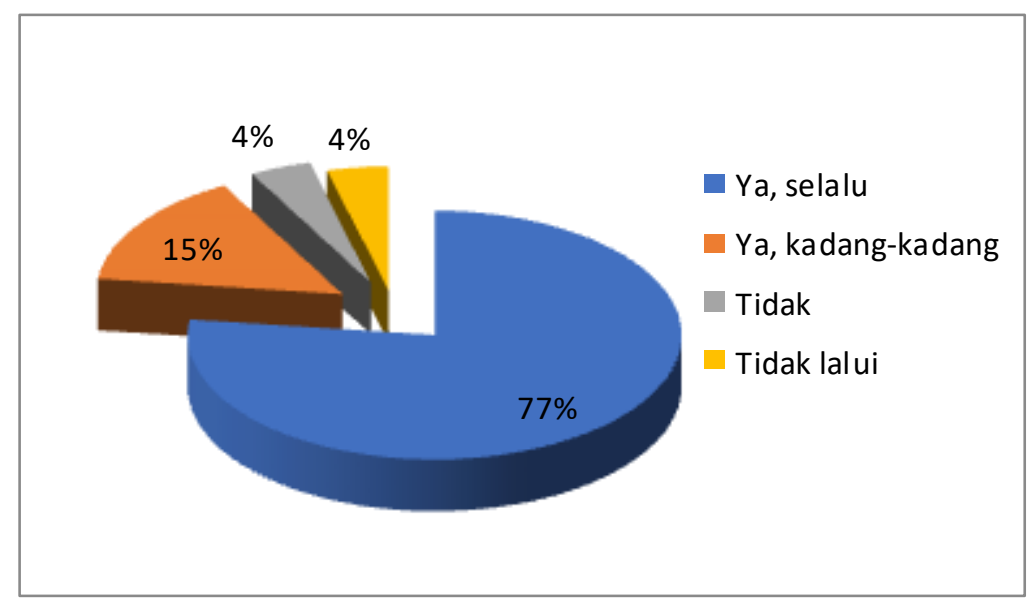

Rajah 8. Pesakit menyuarakan kebimbangan dan kekhuatiran kesihatan kepada doktor

Seterusnya, hanya $15.0 \%$ mengatakan 'Ya, kadang-kadang' mereka akan menyatakan kebimbangan mereka mengenai kesihatan kepada doktor. Pesakit-waris menjelaskan bahawa mereka memahami bahawa doktor berhadapan dengan kesibukan untuk merawat pesakit lain dan pesakit cuba bertoleransi dari segi masa untuk tidak menyuarakan kebimbangan yang dialami oleh mereka pada sepanjang masa. Hanya pada masa tertentu sahaja pesakit-waris menyuarakan kebimbangan. Seramai, 4.0\% pesakit-waris 'Tidak' pernah berkomunikasi dengan doktor untuk meyuarakan kebimbangan atau kekhuatiran. Sebanyak $4.0 \%$ pesakit-waris 'Tidak pernah lalui' situasi untuk menyatakan kebimbangan mereka kepada doktor.

c. Persepsi layanan doktor-pesakit

Untuk menjayakan profesion serta tanggungjawab sebagai seorang pengamal perubatan, individu perlu bertindak dengan pelbagai cara untuk menunjukkan rasa hormat terhadap harga diri dan nilai ke arah mencapai keadilan sosial. Doktor dan kakitangan memberi layanan hormat semasa menjalankan rawatan di pusat perubatan telah mencatat $79.0 \%$ daripada pesakit-waris. Namun 
begitu, terdapat $19.0 \%$ beranggapan hanya 'Ya, kadang-kadang', merasakan mereka dilayan hormat dalam kalangan doktor dan kakitangan pusat perubatan.

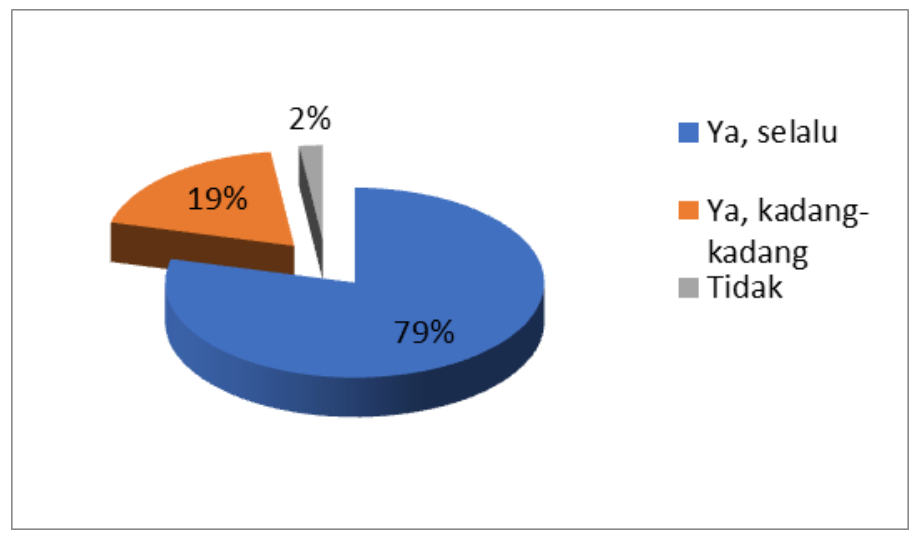

Rajah 9. Persepsi layanan doktor-pesakit

Sejumlah 2.0\% memilih jawapan mereka 'Tidak' merasakan mereka mendapat layanan hormat. Ketika berkomunikasi, pertuturan bahasa dan intonasi suara perlu dikawal dan pengawalan emosi dengan baik ketika berhadapan dengan masalah pesakit. Contohnya, ada responden yang berkongsi pengalaman beliau menangis semasa berada di dalam wad kerana dimarahi oleh doktor atas sebab tidak mengikut peraturan yang betul seperti pengambilan makanan dan ubat yang tidak teratur.

\section{d. Peluang waris berinteraksi bersama doktor}

Berdasarkan Rajah 10, 62.0\% responden berpendapat waris sepenuhnya diberi peluang untuk berinteraksi bersama doktor sekiranya memerlukan sebarang penjelasan berkenaan rawatan kesihatan pesakit. Seramai $29.0 \%$ berpendapat 'Ya, sedikit sebanyak', berpeluang untuk berinteraksi bersama doktor.

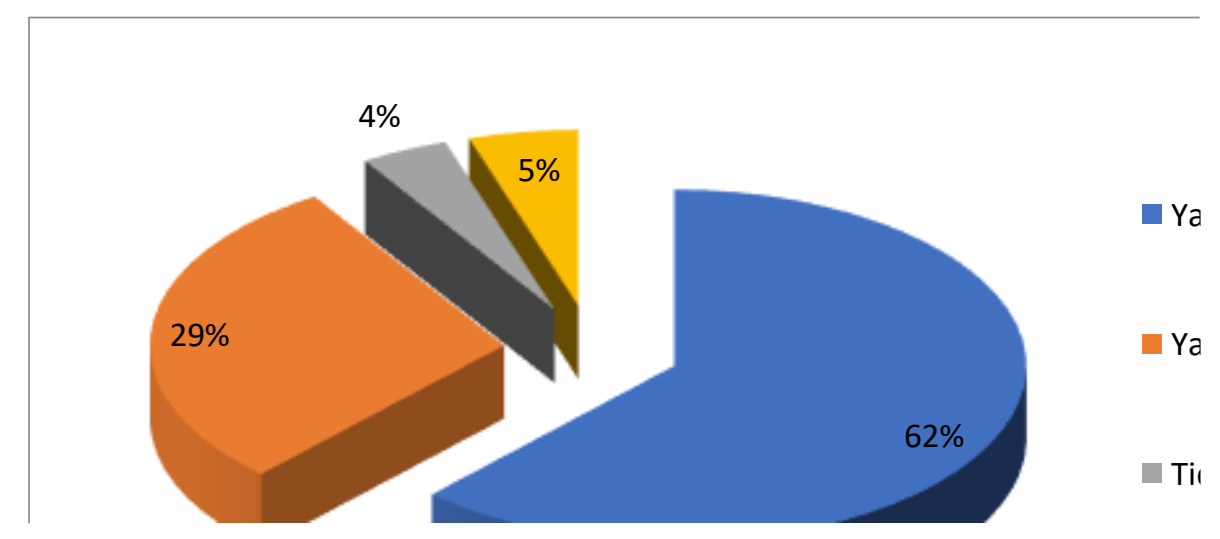

Rajah 10. Waris berpeluang berinteraksi bersama doctor

Rajah 10 turut menunjukkan bahawa 4.0\% menunjukkan peluang untuk mereka sebagai waris berbincang dengan doktor adalah tipis. Manakala, 5.0\% waris berpendapat, doktor hanya berinteraksi dengan pesakit sahaja dan tidak memberi penerangan yang menyeluruh kepada 
waris mengenai perkembangan kesihatan pesakit. Menurut Miric et al. (2008), doktor perlu memberi respons dan peluang kepada pesakit baik secara lisan atau bukan lisan dan perhatian yang sewajarnya dengan menampilkan sifat menghormati pesakit-waris.

\section{Cadangan pesakit-waris terhadap perkhidmatan perubatan}

Jadual 2 berikut merupakan hasil analisis bagi cadangan yang dikemukakan oleh pesakit-waris terhadap usaha mempertingkatkan kualiti perkhidmatan pusat perubatan. Cadangan pesakit-waris terhadap doktor, $42.0 \%$ pesakit-waris mencadangkan agar pihak pusat perubatan meningkatkan bilangan doktor untuk membantu merawat kesihatan pesakit. Sejumlah $12.0 \%$ pula berpendapat bahawa doktor perlu mempertimbangkan penggunaan bahasa yang mudah untuk difahami oleh pesakit-waris. Ini menunjukkan tahap komunikasi di pusat perubatan ini berada di tahap yang memuaskan.

Jadual 2. Cadangan pesakit-waris terhadap perkhidmatan perubatan

\begin{tabular}{cc}
\hline \multicolumn{1}{c}{ Cadangan } & Peratus $(\%)$ \\
\hline Cadangan kepada doktor & 42.0 \\
- $\quad$ Mempertingkatkan bilangan doktor & 12.0 \\
- $\quad$ Penggunaan bahasa yang mudah difahami kepada pesakit-waris & 8.0 \\
- $\quad$ Mempertingkatkan etika komunikasi & 25.0 \\
Cadangan kepada kakitangan & 15.0 \\
- Menjaga adab dan etika semasa bertugas di dalam wad & 22.0 \\
- Sentiasa peka dengan keperluan pesakit & 26.0 \\
- Memberi senyuman & \\
- Memberi arahan dan penerangan yang jelas tentang tindakan pesakit dan & \\
\hline
\end{tabular}

Selain itu, $26.0 \%$ pesakit-waris berpendapat kakitangan pusat perubatan perlu memberi arahan dan penerangan yang jelas tentang tindakan pesakit dan tujuan pengambilan ubat-ubatan. Peratusan kedua paling tinggi adalah menjaga adab dan etika semasa bertugas di dalam wad dengan 25.0\%. Manakala, 22.0\% berpendapat kakitangan pusat perubatan perlu mempertingkatkan budaya sentiasa tersenyum. Pesakit-waris juga berpendapat $15.0 \%$, kakitangan pusat perubatan perlu peka dengan keperluan pesakit.

\section{Kesimpulan}

Menerusi kajian ini, pengkaji berpendapat bahawa dalam khidmat perubatan doktor-pesakit, walaupun peratusan statistik kepuasan pelanggan mencatat peratusan yang agak tinggi bagi komponen tertentu yang dianalisis. Walau bagaimanapun, adalah signifikan dan relevan, perhatian diberi kepada peratusan ketidakpuasan yang mungkin agak kecil. Hal ini berdasarkan sifat profesion kedoktoran bukan sahaja tertumpu kepada kebijaksanaan dan berilmu pengetahuan, tetapi aspek penyampaian maklumat diagnosis dan rumusan status perihal kondisi kesihatan pesakit adalah amat penting. Elemen kejelasan maklumat dalam komunikasi oleh pihak kakitangan perubatan mengandungi beberapa aspek penting yang perlu diberi perhatian. Begitu 
juga kesan hubungan perorangan yang kurang profesional atau kurang 'empati' perlu diberi perhatian.

Penyampaian maklumat yang tidak jelas, contohnya dalam beberapa aspek seperti kesan sampingan ubat-ubatan perlu perhatian iaitu pencapaian peratusan kepuasan pesakit-waris secara keseluruhan boleh ditingkatkan kepada seratus peratus positif dalam sesebuah organisasi pusat perubatan. Bagi komunikasi yang melibatkan hubungan antara perorangan dalam khidmat perubatan memerlukan peratusan tinggi secara keseluruhannya. Hal ini kerana amalan komunikasi perubatan memberi satu gambaran imej positif setiap profesion kepada keseluruhan ahli. Dapatan ini tentunya berupaya untuk mengenal pasti secara terperinci aspek kejelasan maklumat dalam komunikasi yang mampu mempertingkat kesedaran kakitangan pusat perubatan untuk mempertingkatkan amalan khidmat perubatan yang profesional. Hal ini juga membantu untuk dijadikan panduan atau rangka komunikasi doktor dan pesakit-waris yang standad tentang tingkah laku dalam menjalankan perkhidmatan secara beretika serta memiliki ciri-ciri seperti akauntabiliti. Oleh itu, adalah penting dan bersesuaian jika 'suara' daripada pesakit-waris melalui analisa persepsi mereka diteroka seperti yang telah diberikan penekanan dalam kajian ini.

\section{Penghargaan}

Ucapan penghargaan bagi pembiayaan dana GUP-2016-066 Universiti Kebangsaan Malaysia

\section{Rujukan}

Ahrens, S.L. \& Wirges, A.M. (2013). Using evidence to improve satisfaction with medication side-effects education on a neuro-medical surgical unit. Journal of American Association of Neuroscience Nurses, 45(5), 281-287.

Awang Noh, N., Abdul Wahab, H., \& Abu Bakar Ah, S. H. (2014) Quality of public health services received by immigrant labours: A case study in Klang Valley. Jurnal Sains Kesihatan Malaysia, 12(1), 47-56.

Beaulieu, C., Haggerty, J.L., Bouharaoui, F., Leverque, J.F., \& Pineault, R. (2011). Antara perorangan communication from the patient perspective: Comparison of primary healthcare evaluation instruments. Healthcare Policy. 7(2), 108-125.

Benson, B.J. (2014). Domain of competence: Interpersonal and communication skills. Journal of Interpersona; Communication Skills, 14(2), 55-65.

Dickert, N.W., \& Kass, N. E. (2009). Understanding respect: Learning from patients. Journal of Medical Ethics, 35(7), 419-423.

Florian, P. (2008). The value of ethics in health communication. Journal of Medicine and Life, 1(4), 363-368.

Gunasegaran, K. (2014). Medical professionalism from a socio-cultural perspective: Evaluating medical residents' communicative attitudes during the medical encounter in Malaysia. Journal of Postgraduate Medicine, 60(1), 12-16.

Hartley, P. (1993). Interpersonal communication. London, Routledge. 
Jenkinson, C., Coulter, A., \& Bruster, S. (2002). The picker experience questionnaire: Development and validation using data from inpatient surveys in five countries. International Journal for Quality in Health Care, 14(5), 353-358.

Kirkcaldy, A., Jack, B.A., \& Cope, L.C. (2018). Health care profesionals' perceptions of community based 'virtual ward' medicines management service: A qualitative study Research in Social and Administrative Pharmacy, 14(2), 69-75.

Lerman, C., Daly, M., Walsh, W. P., Resch, N., Seay, J., Barsevick, A., \& Martin, G. (1993). Communication between patients with breast cancer and health care providers. Journal of Cancer, 72(9), 2612-2610.

Linebarger, N. (2014). Increased communication between nurses and doctors on an acute medical unit. International Journal for Quality in Health Care, 6(1), 1-12.

McKinley, R.K., \& Robert, C. (2001). Patient satisfaction with out of hours primary medical care. Journal of Quality in Health Care, 10(1), 23-28.

Miric, N.B., \& Bakic, N.M. (2008). Successful doctor-patient communication and rapport building as the key skills of medical practice. Journal of Medicine and Biology, 15(2), 7479.

Pronovost, P., Berenholtz, S., Dorman, T., Lipsett, P.A., Simmonds, A., \& Haraden, S. (2003). Improving communication in the icu using daily goals. Journal of Critical Care, 18(2), 7175.

Ranjan, P., Kumari, A., \& Chakrawarthy, A. (2015). How can doctors improve their communication skill? Journal of Clinical and Diagnostic Research, 9(3), 1-4.

Saiboon, M.I., Ho, S.E., Krishnan, B., Ali, S.N., Murad, N., Pathnathan, A., \& Yin, C.C. (2008). A study of patients' satisfaction with the emergency department (ed) of Pusat Perubatan Universiti Kebangsaan Malaysia (HUKM). Journal of Medicine \& Health, 3(1), 7-13.

Shukla, A.K., Yadav, V.S., \& Kastury, N. (2010). Doctor-patient communication: An important but often ignored aspect in clinical medicine. Journal, Indian Academy of Clinical Medicine. 11(3), 208-211.

Williams, M.V., Davis, T., Parker, R.M., \& Weiss, B.D. (2002). The role of health literacy in patient-physician communication. Journal of Communicating with Special Population, 34(5), 383-389.

Williams, S., Weinman, J., \& Dale, J. (2014). Doctor-patient communication and patient satisfaction: A review. Family Practice - An International Journal, 15(5), 480-492.

Woodhead, S., Lindsley, I., Micallef, C., \& Agius, M. (2015). The doctor patient relationship: What if communication skills are not used? A maltese story. Journal of Psychiatria Danubina, 27(1), 34-40. 